\title{
Character, distribution, and ecological significance of storm wave-induced scour in Rhode Island Sound, USA
}

\author{
Katherine Y. McMullen • Lawrence J. Poppe • Castle E. Parker
}

Received: 11 September 2014 / Accepted: 13 November 2014 / Published online: 21 November 2014

(C) Springer-Verlag Berlin Heidelberg (outside the USA) 2014

\begin{abstract}
Multibeam bathymetry, collected during NOAA hydrographic surveys in 2008 and 2009, is coupled with USGS data from sampling and photographic stations to map the seabed morphology and composition of Rhode Island Sound along the US Atlantic coast, and to provide information on sediment transport and benthic habitats. Patchworks of scour depressions cover large areas on seaward-facing slopes and bathymetric highs in the sound. These depressions average $0.5-0.8 \mathrm{~m}$ deep and occur in water depths reaching as much as $42 \mathrm{~m}$. They have relatively steep well-defined sides and coarser-grained floors, and vary strongly in shape, size, and configuration. Some individual scour depressions have apparently expanded to combine with adjacent depressions, forming larger eroded areas that commonly contain outliers of the original seafloor sediments. Where cobbles and scattered boulders are present on the depression floors, the muddy Holocene sands have been completely removed and the winnowed relict Pleistocene deposits exposed. Low tidalcurrent velocities and the lack of obstacle marks suggest that bidirectional tidal currents alone are not capable of forming these features. These depressions are formed and maintained under high-energy shelf conditions owing to repetitive cyclic loading imposed by high-amplitude, long-period, stormdriven waves that reduce the effective shear strength of the sediment, cause resuspension, and expose the suspended sediments to erosion by wind-driven and tidal currents. Because epifauna dominate on gravel floors of the depressions and infauna are prevalent in the finer-grained Holocene deposits,
\end{abstract}

K. Y. McMullen $(\varangle) \cdot$ L. J. Poppe

U.S. Geological Survey, Coastal and Marine Science Center, Woods Hole, MA 02543, USA

e-mail: kmcmullen@usgs.gov

C. E. Parker

Atlantic Hydrographic Branch, National Oceanic and Atmospheric Administration, 439 West York Street, Norfolk, VA 23510, USA it is concluded that the resultant close juxtaposition of silty sand-, sand-, and gravel-dependent communities promotes regional faunal complexity. These findings expand on earlier interpretations, documenting how storm wave-induced scour produces sorted bedforms that control much of the benthic geologic and biologic diversity in Rhode Island Sound.

\section{Introduction}

Processes associated with sediment erosion, transport, and deposition produce complex patterns of seafloor sedimentary environments and habitats. Understanding the mechanisms controlling these processes and recognizing attributes of the patterns are critical for effective management of coastal resources (e.g., McCann et al. 2011, Rhode Island sector of US Atlantic coast). Earlier work has shown that processes associated with surface waves in conjunction with wind and tidal currents cause significant sediment transport on North American continental shelves (e.g., Gorsline and Grant 1972; Komar et al. 1972; Grant and Madsen 1979; Drake et al. 1985; Goff et al. 2005). The repeated stress caused by oscillatory currents and pressure fields from passing longperiod surface waves reduces the effective shear strength of the sediment resulting in sediment resuspension, while windand tide-driven currents cause net sediment transport (Suhayda et al. 1982; Warner et al. 2008). Observational and modeling studies in Rhode Island Sound (RIS) have reported that storm waves there can exceed threshold friction velocities, facilitating resuspension (e.g., First 1972; Boehm and Quinn 1978; Dalyander et al. 2013). Other work has described complex features that transect the shoreface and inner shelf, and consist of shallow, elongate depressions containing rippled sand and gravel off the U.S. east (e.g., Murray and Thieler 2004; Goff et al. 2005; Oakley et al. 2009; Schwab et al. 2014) and west (e.g., Cacchione et al. 1984; Ferrini and 
Flood 2005; Davis et al. 2013) coasts and globally (Trembanis and Hume 2011, and references therein). These features have been variously called rippled scour depressions, sorted bedforms, and cross-shore swaths.

During a reconnaissance (i.e., spaced line) sidescan-sonar survey of sedimentary environments in 1980, Knebel et al. (1982) described areas of the seafloor in northern RIS as having backscatter patterns of tonal patches and lineations, and attributed these patterns to processes associated with sediment reworking. They also speculated that the patterns could be produced by tidal currents enhanced by oscillatory currents from wind-generated waves. Starting in 2008, the National Oceanic and Atmospheric Administration's (NOAA) National Ocean Service began conducting charting operations in RIS with high-resolution, continuous-coverage multibeam bathymetry. Concurrently, wave-analysis and current-modeling were being conducted as part of the State of Rhode Island's Ocean Special Area Management Plan (Asher et al. 2009; Grilli et al. 2010; Ullman and Codiga 2010), and a wave and current bottom-stress database was constructed by the U.S. Geological Survey (USGS; Dalyander et al. 2013). It was this recent public release of the charting data, collection of verification data, and publication of the oceanographic modeling that facilitated the present study.

The future success of the Rhode Island commercial fishing industry and proper management of its resources are at least in part dependent on an understanding of the factors controlling the distribution and diversity of benthic geologic habitats. Fishing is an important part of this state's economy, and total employment directly connected to harvesting, processing, distributing and selling fish landed by Rhode Island ported vessels exceeds 6,950. Estimated total dockside value of fish caught by these vessels, most of which come from RIS, exceeded $\$ 54$ million during 2010, a total of over 42,000 tons (Hasbrouck et al. 2011).

The purpose of this paper is to use the newly available bathymetric, verification, and modeling data to explore the character and distribution of scour depressions in RIS, to discuss the mechanisms and conditions controlling their formation and evolution, and to speculate on the implications for benthic diversity.

\section{Physical setting}

RIS, which covers an area of over $1,500 \mathrm{~km}^{2}$, is located offshore of Rhode Island and southeastern Massachusetts, bordered on the west by Block Island, on the east by Martha's Vineyard, and on the south by the Atlantic Ocean (Fig. 1). The sound is microtidal; maximum predicted spring tide at the Newport RI tide gauge is $<1.6 \mathrm{~m}$. Shorelines in the sound are classified as mixed-energy wave-dominated shorelines (Hayes 1979).
The sedimentary section beneath RIS overlies a southsoutheasterly dipping basement of mostly pre-Mesozoic gneiss and schist. Overlying the metamorphic bedrock are late Cretaceous-Tertiary coastal plain sediments in the southern part of the sound, and Pleistocene glacial deposits and Holocene fluvial, estuarine, and transitional sediments throughout the sound (Fig. 2; McMaster et al. 1968; O'Hara and Oldale 1980; Needell et al. 1983). The coastal plain sediments, which contain deeply eroded channels, form a cuesta across the southern RIS (McMaster et al. 1968).

A late Wisconsinan glacial advance across RIS is recorded by the Ronkonkoma-Block Island-Nantucket terminal end moraine and the Point Judith-Buzzards Bay recessional end moraine (Fig. 1; McMaster et al. 1968). The RonkonkomaBlock Island-Nantucket moraine, which marks the maximum extent of the Laurentide Ice Sheet at around 25.5-28.1 ka (Peltier and Fairbanks 2006; Balco 2011), dislocated and thrust faulted the coastal plain and overlying deposits. The Point Judith-Buzzards Bay moraine, which partially underlies the study area, records a readvance at about $20.5-22.5 \mathrm{ka}$ during the overall retreat of the Laurentide Ice Sheet (Balco 2011; Poppe et al. 2012a). Where exposed on the seafloor, the submerged sections of the moraines beneath RIS are apparent from bands of gravelly sediment and submarine ridges capped by a lag deposit of gravel and boulders resulting from winnowing of the till and ice-proximal coarse-grained stratified deposits by marine processes (Fig. 2; O'Hara and Oldale 1980).

During glacial recession, Glacial Lake Rhode Island formed behind the end moraines, and outwash sediments, deposited in the lake, added to the total thickness of glacial deposits that in places now exceeds $40 \mathrm{~m}$ (O'Hara and Oldale 1980; Needell et al. 1983; Oakley and Boothroyd 2013). During and after lake drainage, while sea level was near lowstand, rivers cut drainage channels into the glacial deposits, often at the locations of previously eroded valleys (Needell et al. 1983). As sea level rose, estuarine and transitional sediments were deposited, infilling many of the depressions left by the late Pleistocene fluvial erosion; as the transgression migrated across the shelf, the unconformity that now separates the Holocene marine sediments from the underlying older deposits was created (Fig. 2; O'Hara and Oldale 1980; Needell et al. 1983).

Tidal currents in RIS are relatively weak (Haight 1942; Knebel et al. 1982; White and White 2011). Mean nearbottom semidiurnal tidal current speeds measured during a relatively calm summer period in the central sound were 10 $12 \mathrm{~cm} / \mathrm{s}$ (Shonting 1969), and have been reported as low as 6 $\mathrm{cm} / \mathrm{s}$ on the shelf just south of the sound (Twichell et al. 1981). Where constricted, however, the tidal currents can be quite strong and can scour the bottom, such as in the passage between Block Island and the coast of southern Rhode Island (Poppe et al. 2012b). Net transport of water in RIS by 


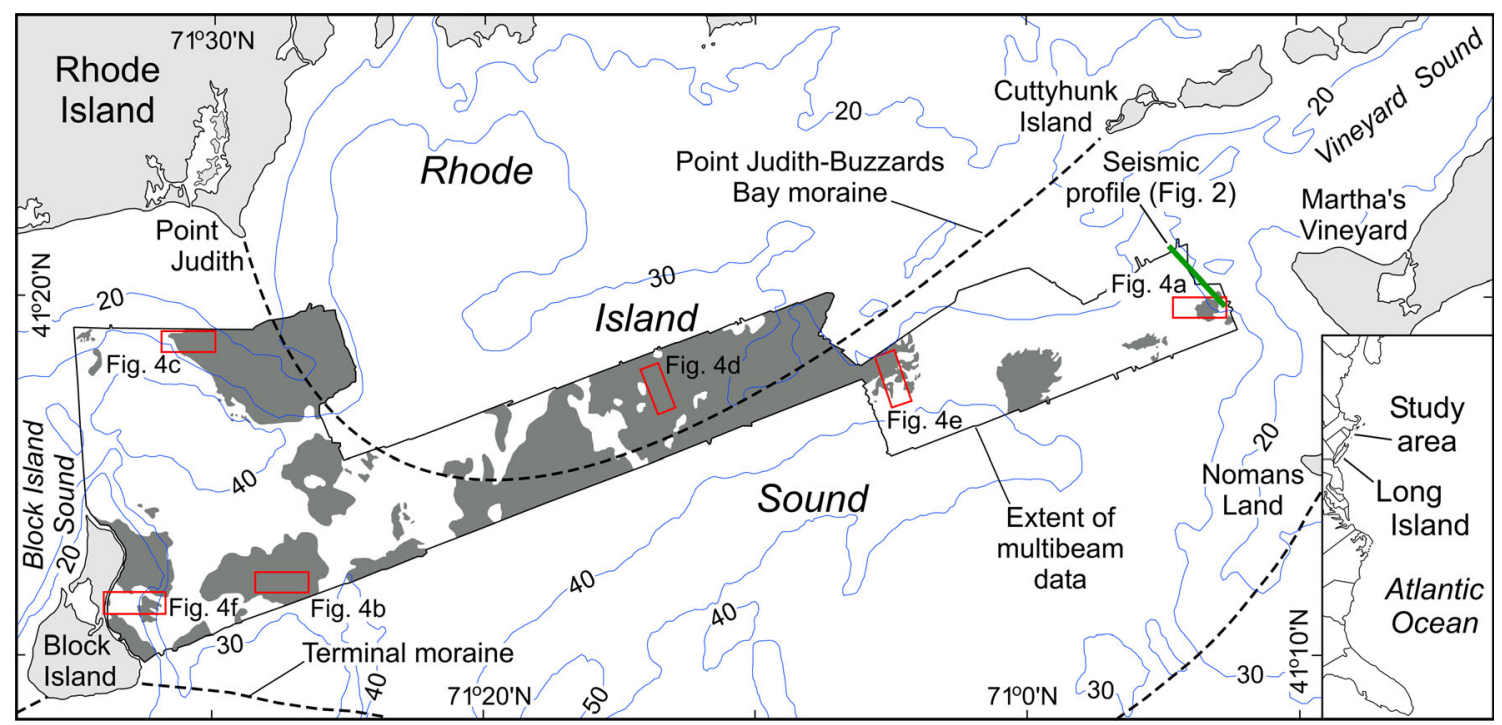

Fig. 1 Map of Rhode Island Sound showing extent of available multibeam bathymetry data, distribution of observed scour depressions (dark gray), local physiographic features, location of seismic profile reported in Fig. 2 (green line), planar views reported in Fig. 4 (open red

the non-constricted tidal currents is minor, and neither their velocity nor magnitude is effective at resuspending bottom sediment (Boehm and Quinn 1978; Dalyander et al. 2013). Thus, fields of sand waves and megaripples are uncommon and, where present, are small (McMullen et al. 2011, 2012; Poppe et al. 2011, 2014).

Wave analysis in RIS has shown that the greatest frequency of waves is from the south and southeast (Asher et al. 2009), and that wave stress is the dominant process affecting
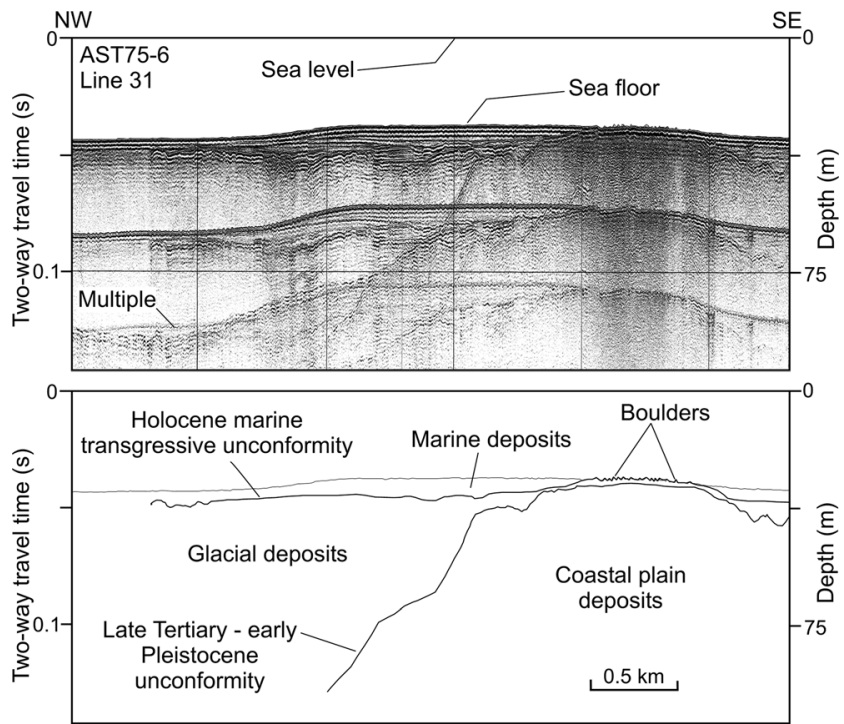

Fig. 2 Segment of a seismic-reflection profile collected in 1975 across a bathymetric high in the eastern part of the study area (extracted from McMullen et al. 2009). The high is cored by coastal plain sediments and mantled by Pleistocene glacial till (cf. O'Hara and Oldale 1980), as evidenced by the presence of boulders in scoured areas on the crest and upper flanks of the high. Location of profile is shown in Fig. 1 polygons), bathymetric contours in meters (blue lines), and approximate axes of submerged segments of the ca. 20.5-22.5 ka and 25.5-28.1 ka end moraines (dashed lines)

sediment mobility, especially during winter (Fig. 3; Dalyander et al. 2013). Average wave heights range from 0.5-2.5 m (Ullman and Codiga 2010), and estimated probable

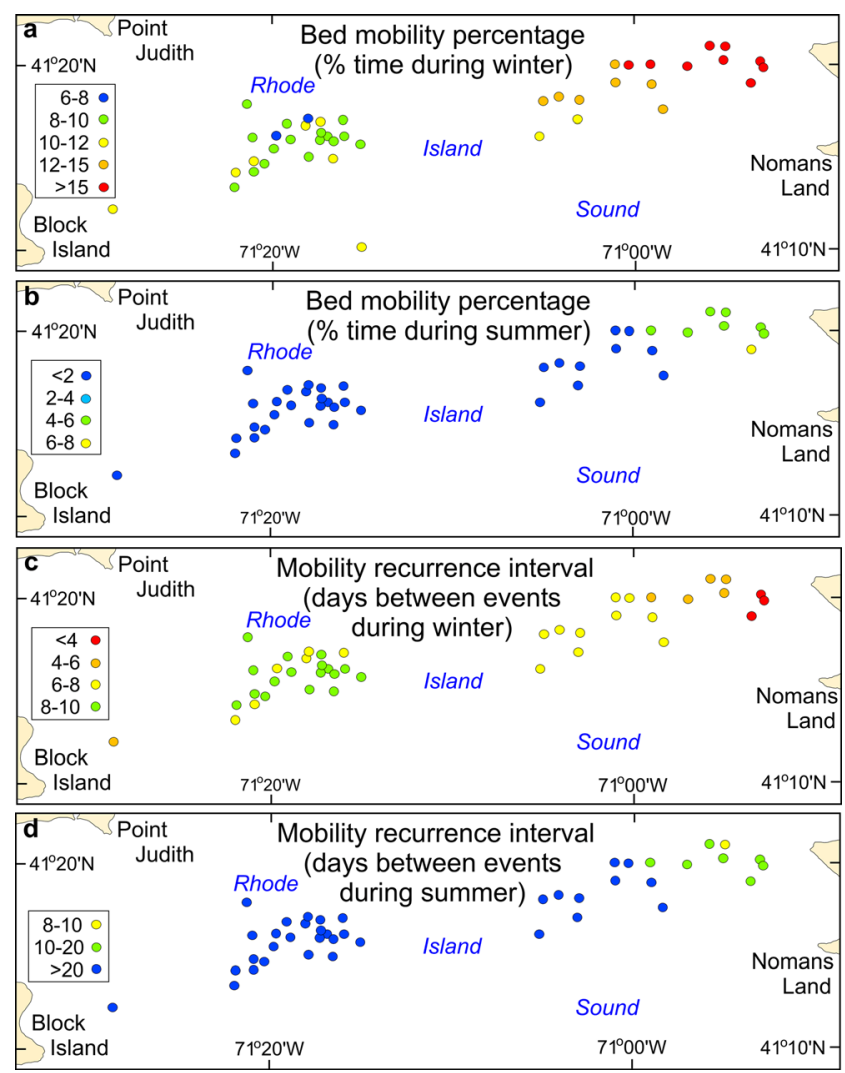

Fig. 3 Plots of bed mobility, displaying the percentage of time critical stress is exceeded, and the mobility recurrence interval, a measure of the frequency of mobility events. Data from the USGS Seafloor Stress and Sediment Mobility Database (Dalyander et al. 2013) 
wave-height extremes are $6.5-7.0 \mathrm{~m}$ for 10-year, 7.5-7.75 m for 25-year, 8.2-8.35 m for 50-year, and 8.8-9.0 m for 100year frequencies (Spaulding 2007; Asher et al. 2009; Grilli et al. 2010). These estimated wave heights, however, are probably low. For example, the NOAA National Data Buoy Center station 44097, located on the shelf just south of RIS $\left(40^{\circ} 58.14^{\prime} \mathrm{N}, 71^{\circ} 7.62^{\prime} \mathrm{W}\right)$, recorded wave heights over $9.3 \mathrm{~m}$ during both 2011 Hurricane Irene and 2012 Hurricane Sandy. Also, studies of modeled wave-induced bottom current velocity have concluded that (1) prolonged $97 \mathrm{~km} / \mathrm{h}$ winds are capable of impacting sediments to a depth of $60 \mathrm{~m}$, and that impact at this depth could occur $1.5-4.9 \%$ of the time (First 1972), and (2) based on numerical modeling at 42 stations from within the area covered by the multibeam bathymetry of this present study, sediment is mobilized about $12.4 \%$ of the time during winter, and episodes of mobility occur at an average interval of 7.0 days (Fig. 3; Dalyander et al. 2013). During calm periods of summer months the sound becomes more stratified (Shonting 1969), potentially resulting in seasonal generation of large-amplitude internal waves that could affect the seabed. Although these waves have been observed on the outer continental shelf south of RIS (Henyey et al. 2006), internal waves have not been reported in the sound.

\section{Materials and methods}

The multibeam-bathymetric data presented herein were acquired for hydrographic charting applications during 2008 and 2009 aboard the NOAA ship Thomas Jefferson. These data, which together cover approximately $445 \mathrm{~km}^{2}$ of the seafloor, were acquired during surveys H11922, H11995, H11996, H12009, H12010, and H12011, and were primarily collected using the ship's hull-mounted, 400-kHz Reson 7125 multibeam echo-sounder system (Fig. 1). Shallow areas within RIS were surveyed by launches equipped with hullmounted 455-kHz Reson Seabat 8125 and 400-kHz Reson 7125 multibeam echo-sounder systems. Vertical resolution of the multibeam data is $0.5 \%$ of the water depth. The bathymetric datasets were acquired by NOAA, digitally logged with HYPACK Hysweep, and processed using CARIS Hydrographic Image Processing System (HIPS) software for quality control and to incorporate sound velocity and tidal corrections. The resultant BASE surfaces were combined into 2-m and 4-m ArcRaster grids, and converted to digital imagery that are vertically exaggerated $(5 \times)$ and hill-shaded (illuminated from $0^{\circ}$ north at an angle of $45^{\circ}$ above the horizon). Detailed descriptions of the multibeam echo-sounder acquisition and processing by NOAA can be found in the Descriptive Reports available through the National Geophysical Data Center (e.g., NOAA 2008).

Sediment sampling and bottom photography were conducted to verify the acoustic data during July-September 2010 and
June 2011 aboard the RV Rafael. Surficial sediment samples $(0-2 \mathrm{~cm}$ below the sediment-water interface) and bottom photography were collected at 108 stations with a modified Van Veen grab sampler equipped with still- and video-camera systems. The photographic data, which included 477 still photographs and over $5 \mathrm{~h}$ of video, were used to appraise intra-station bottom variability, faunal communities and sedimentary structures (indicative of geological and biological processes), and to document cobble and boulder fields where samples could not be collected.

In the laboratory, sediment samples were disaggregated and wet sieved to separate the coarse and fine fractions. The fine fraction $(<63 \mu \mathrm{m})$ was analyzed by Coulter counter, and the coarse fraction by sieving. A detailed discussion of the laboratory methods employed is given in Poppe et al. (2005).

The interpretations of seafloor features, surficial sediment distributions, and sedimentary environments presented herein are based on sediment-sample, bottom-photography, and multibeam-bathymetry data. Readers interested in accessing the processed data for the surveys can do so at: H11922, Poppe et al. (2011); H11996, McMullen et al. (2011); H11995, McMullen et al. (2012); and H12009, H12010, H12011, Poppe et al. (2012b).

\section{Results}

Modern marine sediments of RIS are dominated by medium to coarse sand in shallower areas, and poorly sorted finegrained sand and silty sand in lower-energy, deeper waters. These sediments have a flat, commonly featureless appearance in the multibeam data (Fig. 4), but are faintly rippled to undulating and heavily bioturbated in the bottom photography (Fig. 5a, c, e, g). The abundance of worm tubes, amphipod communities, scattered mollusk valves (primarily Mercenaria sp.), and small to large burrows observed in bottom photography reflects the infaunal richness and diversity in the modern sediments. Mobile fauna commonly observed in the bottom photography include shrimp, spider (Libinia sp.) and cancer (Cancer sp.) crabs, skate, and flounder.

Also present within the areas characterized by these Holocene sediments are patchworks of depressions presumably formed by scour. These depressions are prevalent on the inner continental shelf on the tops and upper flanks of isolated bathymetric highs (Fig. 4a, b), on shoreface-attached largescale ridges such as the submerged extension of the Point Judith moraine (Fig. 4c), on seaward-facing slopes (Fig. 4d, e), and at the transition from lower shoreface (i.e., that part of the shoreface lying below the fair-weather wave base) to inner shelf, such as off the east coast of Block Island (Fig. 4f). They are scattered and discontinuous in the eastern and western parts of RIS, but become more pervasive in the 

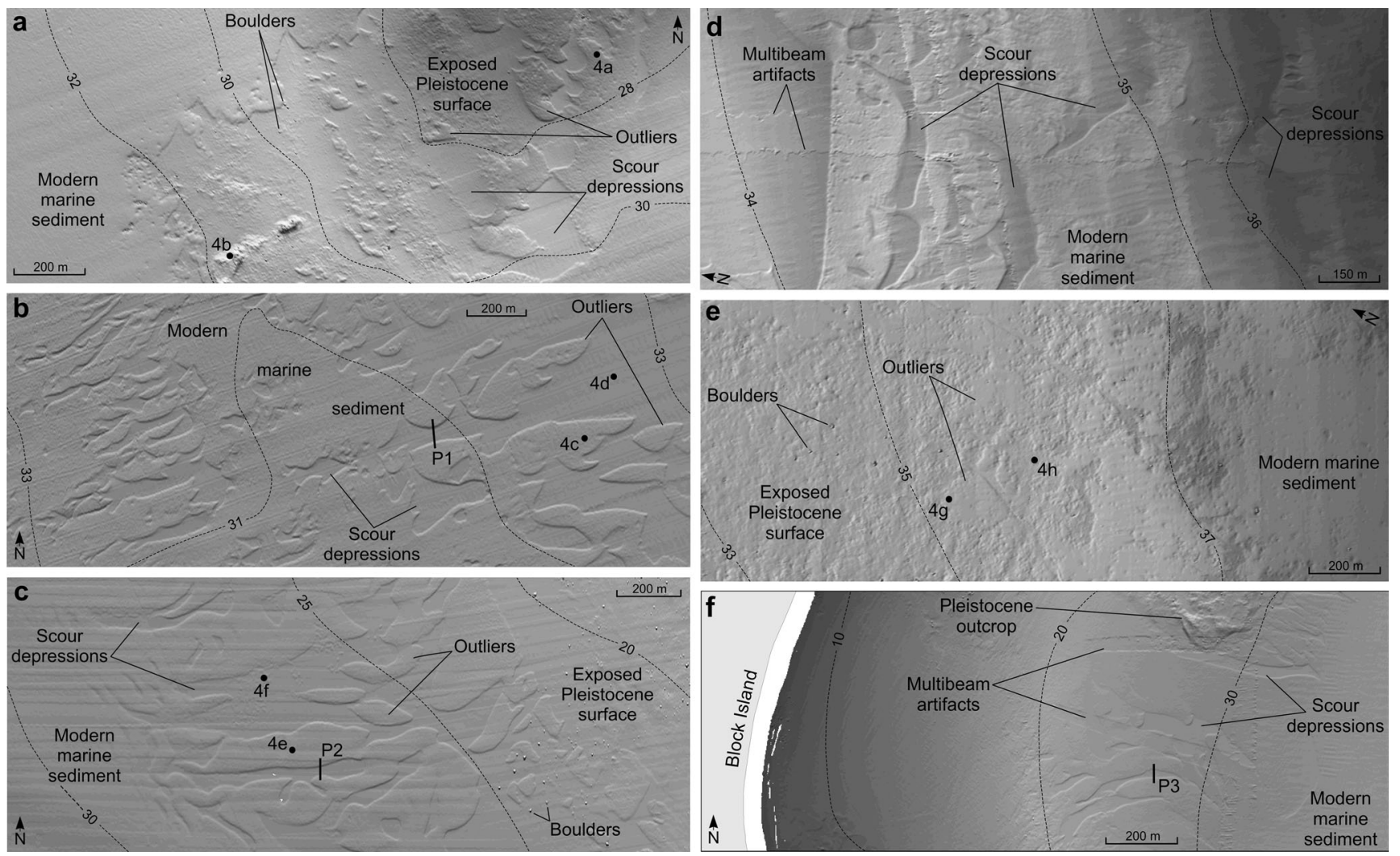

Fig. 4 Detailed planar views of digital terrain models produced from multibeam bathymetry data collected during NOAA hydrographic surveys in RIS (depth contours in meters), showing scour depressions, and locations of bottom photographs (circles) of Fig. 5 and bathymetric profiles of Fig. 6 (thick lines). a Crest of isolated bathymetric high with exposed Pleistocene deposits. b Crest of isolated bathymetric high at the

central, less sheltered part of the sound (Fig. 1). Tops of isolated bathymetric highs with scour depressions range in depth from 26 to $34 \mathrm{~m}$ and have 2 to $8 \mathrm{~m}$ of relief over the surrounding seafloor; the crest of the Point Judith moraine shallows to about $17 \mathrm{~m}$ within the study area.

The scour depressions have relatively steep $\left(3-5^{\circ}\right)$, welldefined sides and average $0.5-0.8 \mathrm{~m}$ deep. Transitions from the floors of the scour depressions to the surrounding modern marine sediments occur within 5-15 m. Individual depressions range from less than $20 \mathrm{~m}$ to over $100 \mathrm{~m}$ in width, and can extend to almost $1 \mathrm{~km}$ in length. They occur in water depths reaching as much as $42 \mathrm{~m}$, but increase in extent and abundance as depths shoal. Some of the depressions are distinct and conspicuous; others are complex, patchy, and discontinuous. The scour depressions exhibit a variety of shapes, sizes, and configurations that range from elongate and narrow to broad and rounded. Elongate morphologies are more common where the depressions are more widely spaced; rounded morphologies are more common near the crests of bathymetric highs and where the scour depressions are abundant and closely spaced. In places, individual scour depressions have apparently coalesced to form larger eroded

southern entrance to RIS. c Southwestern flank of Point Judith moraine. d Seaward-facing slope with scour depressions parallel-subparallel to bathymetric contours. e Seaward-facing slope with small depressions and exposed Pleistocene deposits. f Depressions on lower shoreface and inner continental shelf east of Block Island. For locations of views, see Fig. 1; sun illumination from the north; vertical exaggeration $5 \times$

areas that contain outliers of the original Holocene seafloor sediments (Fig. 4).

Although most of the elongate depressions are oriented roughly east-west, other orientations are present. These features variably straddle bathymetric highs (Fig. 4a, b), extend across slope (Fig. 4c, e), and parallel bathymetric contours (Fig. 4d). Some of the scour depressions connect to larger, shallower scoured areas, but many do not (Fig. 4b, e). Most of the cross-slope depressions terminate on their deeper ends by narrowing and pinching out, but some of the cross-slope depressions shallow and gently merge with the Holocene seabed without narrowing.

Bathymetric profiles across the depressions reveal varying degrees of symmetry (Fig. 6). The deepest parts of the depressions are typically along their southern edges, and the floors of the depressions gradually shoal northward. Where the slopes of opposing sides of the depressions are asymmetrical, the southern side is generally more gradual (Fig. 6, P2). Floors of the depressions viewed in cross-section are flattest within those depressions that parallel the slope of the seafloor (Fig. 6, P3). Asymmetry in the few obstacle marks observed in the multibeam data from RIS is absent. 
Fig. 5 Bottom photographs (for locations, see Fig. 4) showing sediment and various organisms on the seafloor adjacent to (left) and within (right) scour depressions
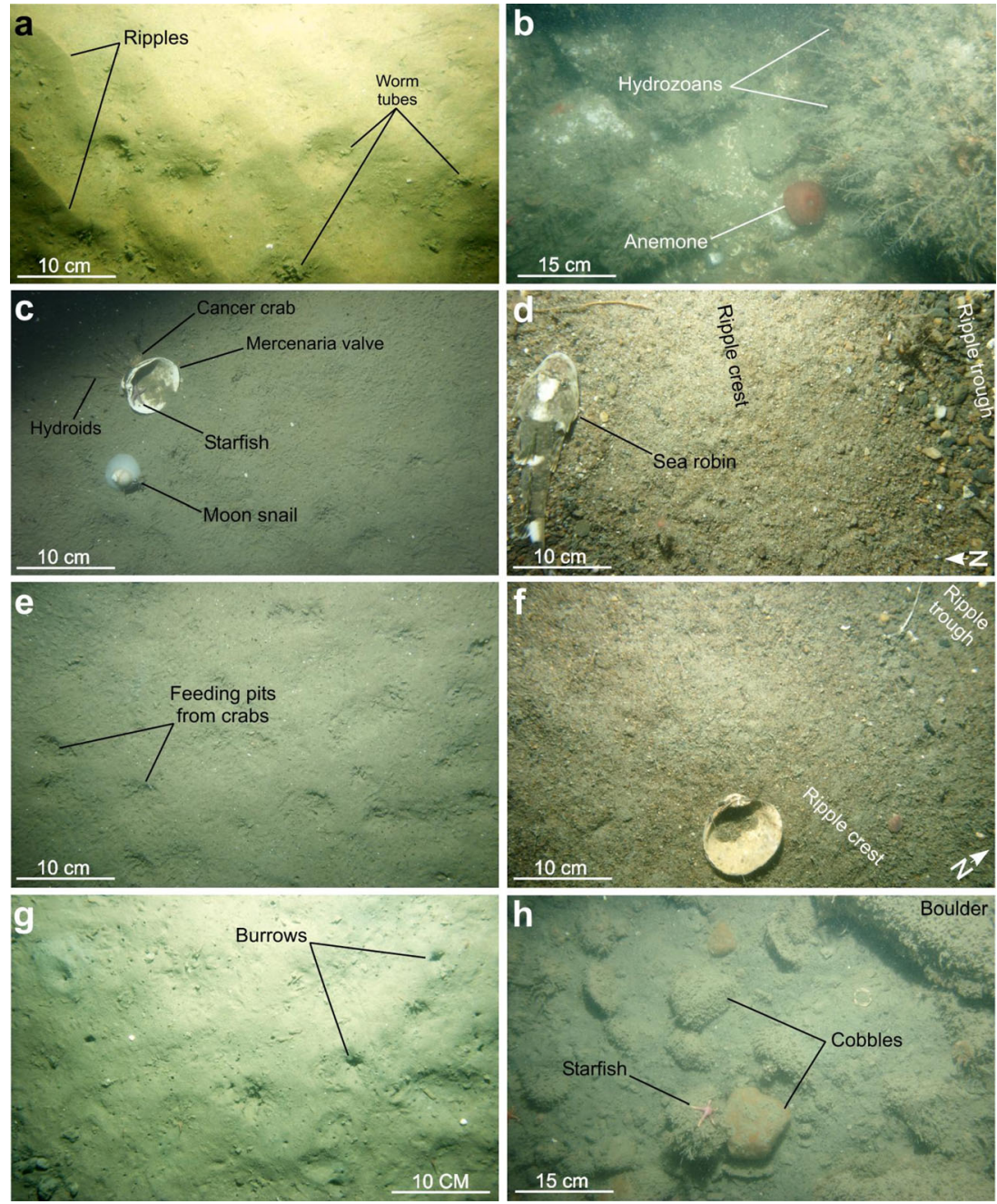

Sediments flooring the scour depressions are invariably coarser grained than those on the surrounding seabed.
Where coarse winnowed deposits of cobbles and boulders floor the scour depressions, the entire Holocene section has
Fig. 6 Bathymetric profiles (for locations, see Fig. 4) across storm wave-induced scour depressions in RIS, with evidence of varying degrees of symmetry. $V E$ Vertical exaggeration

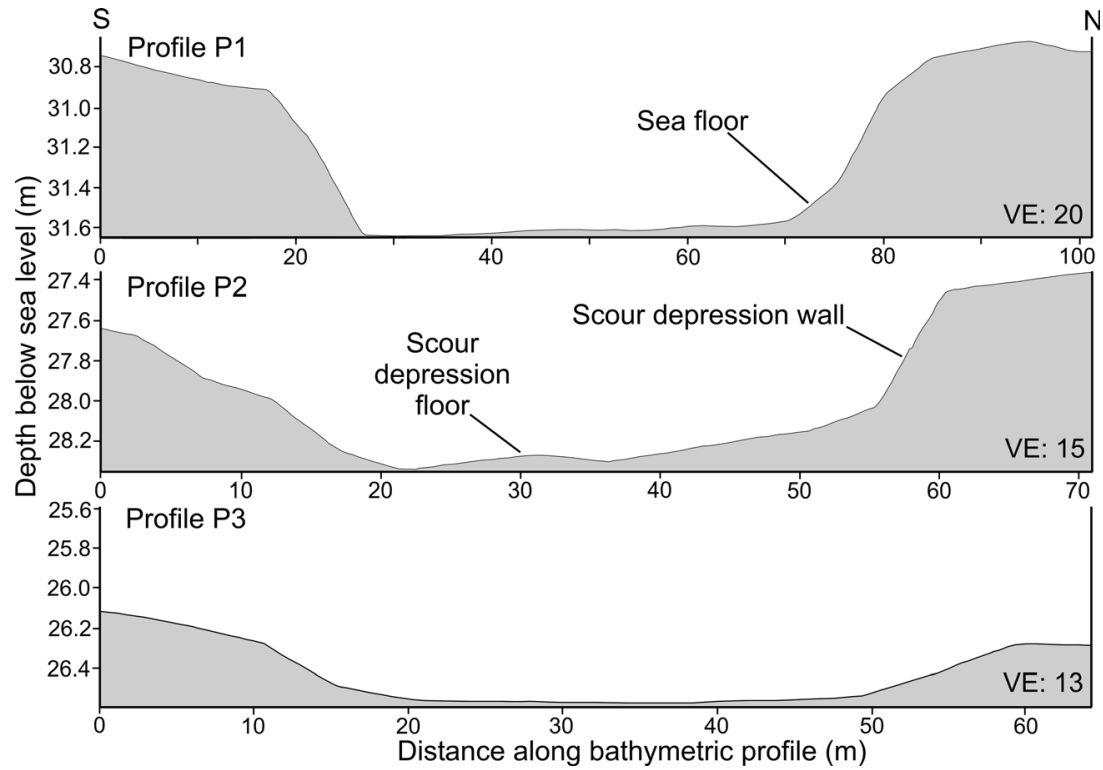


been removed by erosion to reveal underlying lag deposits of Pleistocene glacial till and outwash (Figs. 2, 5b, h). The cobbles and boulders are typically covered by sessile fauna (e.g., hydrozoans, anemones, sponges, corals, barnacles, and hydroids) and, in shallow water, flora (e.g., erect and encrusting algae). Mobile fauna observed in these areas include starfish, cancer and rock crabs, finfish, and lobster. In water more than about $30 \mathrm{~m}$ deep, the lag deposits are also commonly covered by a thin veneer of silt (Fig. 5h). Where sand and gravelly sediment floor the scour depressions, the Holocene section has been only partly removed (cf. McMullen et al. 2009). This sand is typically clean, moderately sorted, and characterized by low (about $10-20 \mathrm{~cm}$ in relief), broad, long-crested, symmetrical or nearly symmetrical ripples with wavelengths of about $1.0 \mathrm{~m}$, and gravelly sand and shell debris concentrated in the ripple troughs (Fig. 5d, f). Mobile fauna observed in these areas include flounder and sea robin. Regardless of setting, shape, or orientation of the depressions, crestlines of the ripples flooring them trend between east-northeast and east-southeast. Although possibly present, no progressive cross-feature changes in sediment texture could be determined with the available data.

\section{Discussion and conclusions}

Modeling and observational studies have long shown that the combined effects of surface waves and currents on the seafloor can extend to considerable depths (e.g., Komar et al. 1972; Suhayda et al. 1982; Drake et al. 1985; Warner et al. 2008). It has also been reported that long-period (infragravity) swell from distant storm systems to the south and southeast and wind-generated waves from local storms moving up the coast can produce large changes in bottom pressure at the RIS seabed (Thompson 1977; Spaulding 2007; Asher et al. 2009; Ullman and Codiga 2010). Although RIS is not an area regularly impacted by hurricanes, frequent intense extratropical storms called Nor'easters and Sou'easters generate strong cross-shelf pressure gradients, produce large waves and strong wind-generated currents, and result in offshore sediment resuspension (McCann et al. 2011).

Orbital motion associated with the high-amplitude, longperiod waves alone can effectively move water down to the wave base, a water depth equal to one half of the wavelength, and the effects of pressure forces can extend much deeper (Suhayda et al. 1982). As the large, long-period storm waves repeatedly pass over a seabed that is shallower than the wave base, repetitive cyclic loading, possibly compounded by gases from biologic activity (Judd and Hovland 2007), can degrade the effective shear strength of the sediment, making it more susceptible to bottom current-induced shear stress. When the reduced effective shear strength threshold is exceeded, bottom currents resuspend, transport, and rework the seabed sediments.

The near absence of obstacle marks, sand waves and megaripples, and the relatively weak tidal currents in central RIS suggest that storm-generated currents are more important than bidirectional tidal currents in formation of the scour features. Although wave-driven orbital currents are the only currents strong enough to resuspend sediment in RIS, these currents impart an oscillatory motion and are typically ineffective at transport (Komar et al. 1972). The suspended sediment could, however, be advected by any unidirectional current, such as wind-driven currents and the weak tidal currents, and redeposited on the surrounding seafloor.

Once the Holocene surface sediments are removed, coarse gravel and boulders are exposed and sand flooring the depressions is rippled. It is the enhanced turbulence from subsequent storm wave-induced currents flowing around these obstructions and bedforms that facilitates further erosion, limits redeposition of modern sediment, promotes better organized and larger-scale bedforms, and serves to maintain the scoured areas (Grant and Madsen 1979; Murray and Thieler 2004). The thin veneer of silty sediment that covers the exposed rocky lag deposits of Pleistocene till and outwash in deeper water provides further evidence that the erosion by enhanced turbulence is not continuous, but probably episodic and storm related.

The presence and morphology of wave-induced scour depressions in the study area suggest these features are forming and being maintained under the present-day hydrodynamic regime, and are not relict. Otherwise, they would have been obliterated by the relatively high postglacial sedimentation rate on the lower shoreface and inner shelf in RIS (Boehm and Quinn 1978) or by bioturbation. The variability in shape of the scour depressions is probably related to a progression of coalescence. Isolated depressions are typically elongate but, as adjacent depressions expand, they connect and eventually combine to form the more rounded morphologies.

Distribution of the scour depressions is, at least to some extent, physiographically controlled. Scour depressions are pervasive in central RIS, a natural amphitheater that is broadly exposed to wave action from the south and southeast, but are patchy and discontinuous in the more protected areas adjacent to Martha's Vineyard and Block Island (Fig. 1). Although also present on the upper shoreface in Block Island Sound, storm wave-induced scour depressions on the lower shoreface and inner continental shelf are much less common there. The near absence of these features in Block Island Sound may be related to the greater protection from North Atlantic storms afforded by Block and Long islands, and to the more prominent relief of the submerged terminal moraine segment between Block Island and Montauk Point, NY because of its ability to disrupt long-period storm waves (Poppe et al. 2012b). 
The storm wave-induced scour depressions described herein are part of a group of sedimentary features most commonly referred to as sorted bedforms and rippled scour depressions. The features in this group, like those in RIS, are typically elongate, $0.3-1 \mathrm{~m}$ in depth, floored by coarser-grained sediment than on the surrounding seafloor, asymmetrical, and contain low broad symmetrical ripples. The features in RIS, however, have two characteristics that differ from most of the other sorted bedforms described in the literature.

First, most of the sorted bedforms reported in the literature are oriented normal (i.e., perpendicular) to the shoreline and(or) parallel to the slope (Cacchione et al. 1984; Davis et al. 2013) and, where oriented parallel to the shoreline, they are nearshore features probably related to hydrodynamics associated with longshore bars and the surf zone (Ferrini and Flood 2005). Conversely, most of the elongated features in RIS have long-axis orientations between ENE and ESE that are roughly normal to the dominant direction of storm-wave incidence (Asher et al. 2009), and that are apparently independent of shoreline and slope orientation.

Second, most sorted bedforms in the literature contain ripples with crestlines that are oriented normal to the direction of the depression's elongation (Ferrini and Flood 2005). The RIS features, however, contain symmetrical ripples with ENE to ESE oriented crestlines that parallel the direction of depression elongation, suggesting that they are wave-orbital ripples produced by waves propagating from the south (Murray and Thieler 2004; Clifton 2006). Sorted bedforms described off North Carolina (Murray and Thieler 2004), Massachusetts (Goff et al. 2005), and New York (Schwab et al. 2014) have been attributed to enhanced sediment entrainment due to wave interaction with the seabed and bottom roughness elements, and to transverse longshore flow. While wave interaction with bottom roughness elements clearly plays a role in the maintenance of the RIS features, strong sound-wide transverse flows are likely provided by wind-driven currents associated with storms approaching from the south (Ullman and Codiga 2010). Because sorted bedforms have coarse-domain bathymetric lows on their updrift sides (Murray and Thieler 2004; Ferrini and Flood 2005), evidence for a northward transverse flow is provided by the asymmetry of scour depressions in RIS that generally have their deepest parts along their southern edges (Fig. 6, P1, P2).

Linear scour depressions roughly similar in appearance to those present on the lower shoreface off the east coast of Block Island (Fig. 4f) have been previously described on the upper shoreface off southwestern Rhode Island (Oakley et al. 2009) and the west coast of Block Island (Poppe et al. 2012b). These upper-shoreface scour depressions are invariably oriented shore normal and are floored by coarser-grained sediments, but contain small bedforms with shore-parallel crests and extend to depths of only about $20 \mathrm{~m}$. Oakley et al. (2009) argued that these scour depressions were probably formed and maintained by downwelling return flow resulting from storm surge and wave setup. It is clearly unlikely, however, that the sorted bedforms in RIS were formed by this mechanism because they occur in settings on the inner continental shelf away from shorelines, such as on the crests of isolated, relatively deep bathymetric highs of low relief. These are settings where strong return flow from storm surge or wave setup would not be expected to develop.

Regardless of the precise mechanisms by which they form, the storm wave-driven scour described here results in the juxtaposition of seafloor areas in RIS with distinct boulder and gravel, coarse sand, and muddy sand textures. This textural heterogeneity reflects a complex patchwork of contrasting sedimentary environments that, in turn, creates contrasting epifaunal- and infaunal-dominated habitats (Hallenbeck et al. 2012). The coarse lag deposits of Pleistocene till and glacial outwash that floor some of the scour depressions reflect higher-energy sedimentary environments characterized by processes associated with erosion and non-deposition. These areas are ecologically important because they shelter finfish, and provide a stable hard substrate for attached and encrusting fauna and flora that add to the overall benthic roughness (Harris and Baker 2012). The coarse sand that floors the deeper scour depressions and the muddy sand of the surrounding Holocene deposits support extensive infaunal communities and reflect contrasting lower-energy sedimentary environments characterized by processes associated with sorting, reworking, and deposition.

Earlier work completed elsewhere off the northeastern US has demonstrated such relationships between benthic organisms, sediment texture and hydrodynamics, and concluded that seafloor heterogeneity promotes species richness (e.g., Rhoads 1974; Snelgrove and Butman 1994; Zajac et al. 2000a). Furthermore, other studies off southern New England have concluded that benthic community structures exhibit significant changes and infaunal species populations are enhanced within transition zones (Reid et al. 1979; Zajac et al. 2000b). In RIS, contacts between the scoured areas and surrounding Holocene sediments form an extensive network of narrow transition zones, resulting in small-scale textural and biological heterogeneity that likely adds to the regional sound-wide benthic diversity.

In conclusion, it is contended that (1) resuspension by large-amplitude long-period storm waves, coupled with transport of the resuspended sediment by the relatively weak tidal and wind-generated currents, creates the scour depressions observed in Rhode Island Sound; (2) these depressions are a variety of sorted bedforms that strongly affect the distributions of sedimentary environments, controlling much of the sound's geologic diversity; and (3) the geologic diversity promotes benthic biologic diversity. 
Acknowledgements We thank the officers and crew of NOAA Ship Thomas Jefferson, who collected the bathymetric datasets, Seth Ackerman and Bill Danforth (USGS) for assistance with data processing, and Brad Butman and Harley Knebel for their helpful discussions. This work was supported by the Coastal and Marine Geology Program of the U.S. Geological Survey and the Atlantic Hydrographic Branch of the National Oceanic and Atmospheric Administration. This manuscript has benefited from critical internal reviews by Bill Schwab and Soupy Dalyander (both USGS), and external reviews by Bryan Oakley, Ralph Lewis and an anonymous reviewer. The use of commercial names is for descriptive purposes only and does not imply endorsement by the USGS or NOAA.

\section{References}

Asher TG, Grilli A, Grilli ST, Spaulding ML (2009) Analysis of extreme wave climates in Rhode Island waters. Rhode Island Ocean Special Area Management Plan, University of Rhode Island, Ocean SAMP document, Chapter 2. http://www.crmc.ri.gov/samp_ocean/ finalapproved/RI Ocean_SAMP.pdf, accessed 1 July 2014

Balco G (2011) Contributions and unrealized potential contributions of cosmogenic-nuclide exposure dating to glacier chronology, 1990 2010. Quat Sci Rev 30:3-27

Boehm PD, Quinn JG (1978) Benthic hydrocarbons of Rhode Island Sound. Estuar Coast Mar Sci 6:471-494

Cacchione DA, Drake DE, Grant WD, Tate GB (1984) Rippled scour depressions on the inner continental shelf off central California. J Sediment Petrol 54:1280-1291

Clifton EH (2006) A re-examination of facies models for clastic shorelines. In: Posamentier HW, Walker RG (eds) Facies models revisited. SEPM Spec Publ 84:293-337

Dalyander PS, Butman B, Sherwood CR, Signell RP, Wilkin JL (2013) Characterizing wave- and current-induced bottom shear stress: U.S. middle Atlantic continental shelf. Cont Shelf Res 52:73-86

Davis AC, Kvitek RG, Mueller CB, Young MA, Storlazzi CD, Phillips EL (2013) Distribution and abundance of rippled scour depressions along the California coast. Cont Shelf Res 69:88-100

Drake DE, Cacchione DA, Karl HE (1985) Bottom currents and sediment transport on San Pedro shelf, California. J Sediment Petrol 55:15-28

Ferrini VL, Flood RD (2005) A comparison of rippled scour depressions identified with multibeam sonar: Evidence of sediment transport in inner shelf environments. Cont Shelf Res 25:1979-1995

First MW (1972) Municipal waste disposal by shipborne incineration and sea disposal of residues. Harvard University School of Public Health, Boston, MA

Goff JA, Mayer LA, Traykovski P, Buynevich I, Wilkens R, Raymond R, Glang G, Evans RL, Olson H, Jenkins C (2005) Detailed investigation of sorted bedforms, or "rippled scour depressions", within Martha's Vineyard Coastal Observatory, Massachusetts. Cont Shelf Res 25:461-484

Gorsline DS, Grant DJ (1972) Sediment textural patterns on the San Pedro shelf, California (1951-1971): reworking and transport by waves and currents. In: Swift JP, Duane DB, Pilkey OH (eds) Shelf sediment transport: Process and pattern. Dowden, Hutchinson, and Ross, Stroudsburg, pp 575-600

Grant WD, Madsen OS (1979) Combined wave and current interactions with a rough bottom. J Geophys Res 84:1797-1808

Grilli AR, Asher TG, Grilli ST, Spaulding ML (2010) Analysis of extreme wave climates in Rhode Island waters south of Block Island. Rhode Island Ocean Special Area Management Plan Technical Rep 8. http://seagrant.gso.uri.edu/oceansamp/pdf/ appendix/08-AGrilli-STWAVE.pdf, accessed 30 June 2014
Haight FJ (1942) Coastal currents along the Atlantic coast of the United States. US Coast and Geodetic Survey Spec Publ 230

Hallenbeck TR, Kvitek RG, Lindholm J (2012) Rippled scour depressions add ecologically significant heterogeneity to soft-bottom habitats on the continental shelf. Mar Ecol Prog Ser 468:119-133

Harris PT, Baker EK (eds) (2012) Seafloor geomorphology as benthic habitat. GeoHAB Atlas of Seafloor Geomorphic Features and Benthic Habitats. Elsevier, Waltham

Hasbrouck EC, Scotti J, Stent J, Hasbrouck EG, Gerbino K (2011) Rhode Island commercial fishing and seafood industries - the development of an industry profile. Cornell Cooperative Extension Marine Program, NOAA Award \# NA10NMF4720480, Final Report. http://ccesuffolk.org/assets/Marine-photos/Marine-Pdfs/FinalReports/RI-Summary-Doc-2nd-print-s.pdf, accessed 31 July 2014

Hayes MO (1979) Barrier island morphology as a function of tidal and wave regime. In: Leatherman SP (ed) Barrier islands from the Gulf of St. Lawrence to the Gulf of Mexico. Academic Press, New York, pp 1-27

Henyey FS, Tang D, Williams KL, Lien R-C, Becker KM, Culver RL, Gabel PC, Lyons JE, Weber TC (2006) Effect of nonlinear internal waves on midfrequency acoustic propagation on the continental shelf. J Acoust Soc Am 119:3345. doi:10.1121/1.4808854

Judd AG, Hovland M (2007) Seabed fluid flow - the impact on geology, biology and the marine environment. Cambridge University Press, New York

Knebel HJ, Needell SW, O'Hara CJ (1982) Modern sedimentary environments on the Rhode Island inner shelf, off the eastern United States. Mar Geol 49:241-256

Komar PD, Neudeck RH, Kulm LD (1972) Observations and significance of deep-water oscillatory ripple marks on the Oregon continental shelf. In: Swift JP, Duane DB, Pilkey OH (eds) Shelf sediment transport: Process and pattern. Dowden, Hutchinson, and Ross, Stroudsburg, pp 601-620

McCann J, Carnevale MA, Beutel D, Costa-Pierce B, Crean T et al. (2011) Rhode Island Ocean Special Area Management Plan. University of Rhode Island Coastal Resources Center, Volume 1. Rhode Island Coastal Resources Management Council. http://www. crmc.ri.gov/samp_ocean/finalapproved/RI_Ocean_SAMP.pdf, accessed 1 July 2014

McMaster RL, LaChance TP, Garrison LE (1968) Seismic-reflection studies in Block Island and Rhode Island Sounds. Am Assoc Petrol Geol Bull 52:465-474

McMullen KY, Poppe LJ, Soderberg NK (2009) Digital seismicreflection data from eastern Rhode Island Sound and vicinity, 1975-1980. US Geological Survey Open-File Rep 2009-1003. http://pubs.usgs.gov/of/2009/1003/, accessed 30 June 2014

McMullen KY, Poppe LJ, Ackerman SD, Blackwood DS, Schaer JD, Nadeau MA, Wood DA (2011) Surficial geology of the seafloor in central Rhode Island Sound southeast of Point Judith, Rhode Island. US Geological Survey Open-File Rep 2011-1005. http://pubs.usgs. gov/of/2011/1005/, accessed 30 June 2014

McMullen KY, Poppe LJ, Ackerman SD, Worley CR, Nadeau MA, Van Hoy MV (2012) Sea-floor geology in central Rhode Island Sound south of Sakonnet Point, Rhode Island. US Geological Survey Open-File Rep 2012-1004. http://pubs.usgs.gov/of/2012/1004/, accessed 30 June 2014

Murray AB, Thieler ER (2004) A new hypothesis for the formation of large-scale inner-shelf sediment sorting and 'rippled scour depressions'. Cont Shelf Res 24:295-215

Needell SW, O'Hara CJ, Knebel HJ (1983) Quaternary geology of the Rhode Island inner shelf. Mar Geol 53:41-53

NOAA (2008) Descriptive report for survey H11922, Project No. OPRB370-TJ-08. National Ocean Service, National Oceanic and Atmospheric Administration. http://surveys.ngdc.noaa.gov/mgg/ NOS/coast/H10001-H12000/H11922/DR/H11922.pdf, accessed 30 June 2014 
Oakley BA, Boothroyd JC (2013) Constrained age of Glacial Lake Narragansett and the deglacial chronology of the Laurentide Ice Sheet in southeastern New England. J Paleolimnol 50:305-317

Oakley BA, Alvarez JD, Brenner HB, Dowling MJ, Klinger JP, Zitello M, Boothroyd JC (2009) Depositional environments and sediment transport on a microtidal, wave-dominated shoreface. In: Proc Coastal Zone 09, Boston. http://coast.noaa.gov/cz/CZ09 Proceedings/Abstract\%20PDFs/Poster.Oakley.pdf, accessed $1 \overline{7}$ October 2014

O’Hara CJ, Oldale RN (1980) Maps showing geology and shallow structure of eastern Rhode Island Sound and Vineyard Sound, Massachusetts. US Geological Survey Miscellaneous Field Studies Map MF-1186, scale 1:125,000

Peltier WR, Fairbanks RG (2006) Global ice volume and last glacial maximum duration from an extended Barbados sea level record. Quat Sci Rev 25:3322-3337

Poppe LJ, Williams SJ, Paskevich VF (eds) (2005) U.S. Geological Survey east-coast sediment analysis-Procedures, database, and GIS data. US Geological Survey Open-File Rep 2005-1001. http:// pubs.usgs.gov/of/2005/1001/, accessed 1 July 2014

Poppe LJ, McMullen KY, Ackerman SD, Blackwood DS, Irwin BJ, Schaer JD, Forrest MR (2011) Sea-floor geology and character of eastern Rhode Island Sound west of Gay Head, Massachusetts. US Geological Survey Open-File Rep 2011-1004. http://pubs.usgs.gov/ of/2011/1004/, accessed 30 June 2014

Poppe LJ, Oldale RN, Foster DS, Smith SM (2012a) Glaciotectonic deformation associated with the Orient Point-Fishers Island moraine, westernmost Block Island Sound: further evidence of readvance of the Laurentide ice sheet. Geo-Mar Lett 32:279-288

Poppe LJ, Danforth WW, McMullen KY, Blankenship MA, Glomb KA, Wright DB, Smith SM (2012b) Sea-floor character and sedimentary processes of Block Island Sound, offshore Rhode Island. US Geological Survey Open-File Rep 2012-1005. http://pubs.usgs. gov/of/2012/1005/, accessed 30 June 2014

Poppe LJ, McMullen KY, Danforth WW, Blankenship MA, Clos AR, Glomb KA, Lewit PG, Nadeau MA, Wood DA, Parker CE (2014) Combined multibeam and bathymetry data from Rhode Island Sound and Block Island Sound - a regional perspective. US Geological Survey Open-File Rep 2014-1012. http://pubs.usgs. gov/of/2014/1012/, accessed 5 September 2014

Reid RN, Frame AB, Draxler AF (1979) Environmental baselines in Long Island Sound, 1972-1973. National Oceanic and Atmospheric Administration Tech Rep SSRF-738

Rhoads DC (1974) Organism-sediment relations on the muddy seafloor. Oceanogr Mar Biol Annu Rev 12:263-300
Schwab WC, Baldwin WE, Denny JF, Hapke CJ, Gayes PT, List JH, Warner JC (2014) Modification of the Quaternary stratigraphic framework of the inner-continental shelf by Holocene marine transgression: an example offshore of Fire Island, New York. Mar Geol 355:346-360

Shonting DH (1969) Rhode Island Sound square kilometer study: flow patterns and kinetic energy distribution. J Geophys Res 74:3386-3395

Snelgrove PVR, Butman CA (1994) Animal-sediment relationships revisited: cause versus effect. Oceanogr Mar Biol Annu Rev 32: $111-177$

Spaulding M (2007) Wave analysis studies in Rhode Island Sound. Rhode Island Ocean Special Area Management Plan. http://www. crmc.ri.gov/samp_ocean/Wind_Energy_RI_EBC.pdf, accessed 9 July 2013

Suhayda JN, Coleman JM, Whelan T, Garrison LE (1982) Oscillation of continental shelf sediments caused by waves. In: Fanning KA, Manheim FT (eds) The dynamic environment of the ocean floor. DC Heath, Lexington, pp 57-75

Thompson EF (1977) Wave climate at selected locations along the U.S. coasts. US Army Corps Engineers Tech Rep 77-1

Trembanis AC, Hume TM (2011) Sorted bedforms on the inner shelf off northeastern New Zealand: spatiotemporal relationships and potential paleo-environmental implications. Geo-Mar Lett 31:203-214

Twichell DC, McClennen CE, Butman B (1981) Morphology and processes associated with the accumulation of the fine-grained sediment deposit on the southern New England shelf. J Sediment Petrol 51: 269-280

Ullman DS, Codiga DL (2010) Characterizing the physical oceanography of coastal waters off Rhode Island: new observations of water properties, currents, and waves. Rhode Island Ocean Special Area Management Plan, Tech Rep 3. http://seagrant.gso.uri.edu/ oceansamp/pdf/appendix/03-PhysOcPart2-OS AMPUllmanCodiga2010.pdf, accessed 30 June 2014

Warner JC, Butman B, Dalyander PS (2008) Storm-driven sediment transport in Massachusetts Bay. Cont Shelf Res 28:257-282

White RE Jr, White LF (2011) Eldridge tide and pilot book. Robert E. White Instruments, Medfield

Zajac RN, Lewis RS, Poppe LJ, Twichell DC, Vozarik J, DiGiacomoCohen ML (2000a) Relationships between seafloor structure and benthic communities in Long Island Sound at regional and benthoscape scales. J Coast Res 16:627-640

Zajac RN, Lewis RS, Poppe LJ, Twichell DC, Vozarik J, DiGiacomoCohen ML (2000b) Responses of infaunal populations to benthoscape structure and the potential importance of transition zones. Limnol Oceanogr 48:829-842 